\title{
ЯЗЫКОЗНАНИЕ
}

UDC 82

Alexander Yu. Zheltov

\section{COMPARATIVE ANALYSIS OF MORPHEMIC AND SUBMORHEMIC NEUTRALIZATIONS IN BANTU PRONOMINAL PARADIGMS (WHAT THEY ARE FOR, AND WHAT THEY SAY ABOUT THE LANGUAGE CHANGE)}

Saint Petersburg State University, 7-9, Universitetskaya nab., St. Petersburg, 199034, Russian Federation Peter the Great Museum of Anthropology and Ethnography, Russian Academy of Science, 3, Universitetskaya nab., St. Petersburg, 199034, Russian Federation

This paper deals with a comparative analysis of the distribution of morphemic and submorphemic neutralizations in pronominal paradigms of the Bantu languages from different zones distributed into three geographical areas and Proto-Bantu reconstruction. The analysis shows that the neutralizations are not "occasional", but rather systematic. Morphemic and submorphemic neutralizations are often in additional distribution, the more morphemic neutralizations in the paradigm, the less submorphemic ones. It is often important for paradigms to keep the structure of oppositions and neutralizations rather than the forms. All the neutralizations $(1 / 2,2 / 3, \mathrm{sg} / \mathrm{pl})$ take place in all the languages despite the difference in forms. Sometimes $1 / 2$ and $2 / 3$ neutralizations are realized in cascade form (Basaa). It shows that all these neutralizations are crucially important to the 'glue' of pronominal paradigms. $1 \mathrm{sg}$ tends to be in opposition to other pronouns and very seldom participates in neutralizations. 3rd person is "responsible" for $\mathrm{sg} / \mathrm{pl}$ neutralization, plural - for $1 / 2$ neutralization, $2 / 3$ is distributed in both sg. and pl. $1 / 2$ neutralization tends to be submorphemic, while other types of neutralizations can be both morphemic and submorphemic. Refs 11. Tables 3 .

Keywords: morphemic neutralizations, submorphemic neutralizations, Bantu languages, personal pronouns.

\section{СРАВНИТЕЛЬНЫЙ АНАЛИЗ МОРФЕМНЫХ И СУБМОРФНЫХ НЕЙТРАЛИЗАЦИЙ В ПАРАДИГМАХ ЛИЧНЫХ МЕСТОИМЕНИЙ ЯЗЫКОВ БАНТУ}

\section{А. Ю. Желтов}

Санкт-Петербургский государственный университет, Российская Федерация, 199034, Санкт-Петербург, Университетская наб., 7-9

Музей антропологии и этнографии РАН, Российская Федерация, 199034, Санкт-Петербург, Университетская наб., 3

В статье рассматриваются теоретические аспекты морфемной и субморфной нейтрализации, а затем представлен сравнительный анализ морфемных и субморфных нейтрализаций в парадигмах личных местоимений языков банту различных зон и географических ареалов. Представлен языковой материал различных зон языков банту, распределенных на три географических ареала, в сравнении с реконструкцией местоименной системы протобанту. В резуль-

(c) Санкт-Петербургский государственный университет, 2016 
тате проведенного анализа делаются выводы о системном характере нейтрализаций в языках банту, о дополнительной дистрибуции морфемных и субморфных нейтрализаций. Во всех представленных в статье языках можно наблюдать все три возможных типа нейтрализаций: 1/2 лицо, 2/3 лицо, ед. ч./мн.ч.

В некоторых случаях можно наблюдать т.н. «каскадные» нейтрализации: 1/2/3 лицо. 1 лицо ед. ч. проявляет тенденцию не участвовать в процессе нейтрализации, противопоставляясь всем другим формам. В 3 лице чаще проявляется нейтрализация по числу, во мн. ч. нейтрализация $1 / 2$ лица, нейтрализация $2 / 3$ лица встречается как в единственном, так и во множественном числе, чаще всего являясь субморфной. Другие типы нейтрализаций бывают как морфемного, так и субморфного характера. Библиогр. 11 назв. Табл. 3.

Ключевые слова: морфемные нейтрализации, субморфные нейтрализации, языки банту, личные местоимения.

\section{Introduction and methodology}

\subsection{Morphemic neutralization}

Morphemic neutralization is the case when as in Swahili object paradigm the pronouns of 2 and $3 \mathrm{pl}$-wa-coincide. See also German sie for 3 SG. FEM, 3 PL and 2 PL. HONORIFIC and English you for 2 SG/PL. Such cases are often treated as homonymy or syncretism, for instance by Cysow [1], but following Konstantin Pozdniakov [2, 3, 4] can be characterized as morphemic neutralization. The first assumption of Konstantin Pozdniakov which seems to be of great importance is the idea that neutralization is neither something destructive in relation to a certain meaning, nor just occasional expression of "language economy principle". He believes that neutralization is a very important means to mark the presence of oppositional (paradigmatic) relations between the signs, and, hence, the contextual neutralization of opposition, and it serves to show the belonging of the elements to the same dimension, which makes possible to highlight the difference between them. Then, another fundamental position of K. Pozdniakov is the idea that neutralization (homonimy) does not serve to hide the meaningful features (as it is often believed), but is used to create new semantic features, instead. It is the means for creating additional pronominal features rather than an occasional ambiguity, these neutralizations (homonymy) within paradigms being not occasional but very important to mark the oppositional (paradigmatic) relations between the signs and create additional semantics [3].

\subsection{Submorphemic neutralizations}

The notion of submorphemic neutralizations was first introduced by Roman Jackobson [5] who called this phenomenon "primeta" ('mark' in English), and used it for case paradigms in Russian. Further analysis of this phenomenon for pronominal paradigms which are the object of this paper you can find in the works by Pozdniakov [2, $3,4]$, and Zheltov [6, 7]. The cases of partial formal coincidence of neighboring elements in paradigms with common semantic component (eg. "locutor") as in French moi-toi (1/2 SG), nous-vous (1/2 PL); German mich-dich, mir-dir (1/2 SG), Swahili wako-wake 2SG. POSS/ 3SG. POSS are considered. Konstantin Pozdniakov [3] mentions just four scholars who showed their interest to this phenomenon: Roman Jacobson, Alexander Reformatskij, Igor Mel'chuk and Vyacheslav Ivanov. He also mentions various definitions they used for it which are correspondingly: "mark" ("primeta'), "sound marking", "carrier of function", "sound mark". He also illustrates the phenomenon by the example from 
Roman Jacobson [5]. Dative, Instrumental and Locative cases in Russian according to Jacobson's analysis are different from the other cases and marked by the common feature which he called "periphery cases". At the same time all the flexions of these cases (and only of these) in adjectives in masculine gender have the common formal feature $[\mathrm{m}]$ - '-omu', '-ym', 'om'. So, there is a semantic feature (otherwise the semantics of "periphery cases" has no formal exponent) and the formal marking of this feature. The intriguing fact is that this formal marking is segmentally less than morpheme, which hence, loses its status as the minimal meaningful linguistic unit and the question of singling out a new phenomenon arises. Konstantin Pozdniakov calls the process of neutralization of Dative/Instrumental/ Locative distinctions providing the formation of a new semantic feature of "pheriphery cases" which exponent is [m] (labial nasal sonant) "submorphemic paradigmatic neutralization". So he makes a very important step to the inclusion of this phenomenon into linguistic description and the determination of its place in this description.

As it was quite well shown by Pozdniakov in $[2,3,4,8]$ the submorphemic netralizations are of great importance. According to his ideas they are used for "gluing" together the elements of a paradigm with common component of meaning in the same way as morphemic neutralization, but it is more convenient for the language for it keeps the distinction between them at the same time. He points out 2 important generalizations about this phenomenon: 1) both morphemic and submorphemic neutralizations can be observed in a certain paradigm, while other paradigms keep the distinction of forms; 2) morphemic and submorphemic neutralizations tend to be in complementary distribution. As for pronominal paradigms, submorphemic neutralizations are widely used for marking the speech act participants in contrast to 3 person pronouns. It also seems that tonal differences in pronominal system can be treated in the similar way. Tonal patterns can be used both for differing segmentally identical elements turning morphemic neutralization into a submorphemic one (with the only difference in tone), and for "gluing" segmentally different elements with the common semantics by marking them with common tone.

One more important problem discussed by Pozdniakov is the relation of the submorphemic neutralization to the notion of iconicity of linguistic sign and sound symbolism. He believes that the idea of submorphemic neutralization and iconicity have nothing in common. The fact that $[\mathrm{m}]$ means "periphery cases" in adjectival paradigm of masculine gender has nothing in common with iconicity. The common feature of "periphery cases" marked by $[\mathrm{m}]$ is meaningful only in a certain linguistic paradigm and has no reference in natural reality. That can be proved by the fact that in another paradigm $[\mathrm{m}]$ may have no meaning at all or absolutely different one.

Another problem of involving this phenomenon into linguistic description is the heterogeneity of the processes which can be included in it. Now we will try to show in what varieties it exists in pronominal systems. They seem to be the following ones: 1) the borderline of morphemic/submorphemic neutralizations, 2) hidden morphemes, 3) segmental submorphemic (the carrier of meaning has segmental exponent phoneme or a group of phoneme though it is less than morpheme, 4) supra-segmental submorphemic, which can be subdivided into 3 subgroups - a) syllable structure, b) tone (may be stress as well), c) differential features of phonemes (eg. 'fricative', 'nasal' etc.), i.e. all the cases when the exponent of a certain meaning is not segmental. The latter case is of especial interest, as it deals with meanings expressed by the elements less than not only morpheme, but phoneme as well. 
The phenomena of the 1 group are very important because they delete the strict border between morphemic and submorphemic neutralization and, thus, show that the latter is not actually something marginal in the language, but it can be of the same importance for the language semantics as surface morphology. That can be illustrated by the French 3 person pronouns. In not pre-vocal position in spoken language we can interpret the sg$\mathrm{pl}$ forms il /il'/ - ils/il'/ and elle /el'/ - elles / el'/ as the case of morphemic neutralization. For pre-vocal position and written language, where formal distinctions are kept, two variants of interpretation are possible, but all of them seem to contradict the traditional views. We can interpret/il/ and /elle/ elements in 'ils' and 'elles' as the submorphemic mark which signals the submorphemic neutralization of number distinctions in another context being neutralized. Another interpretation is to consider them as the morphemes without number distinction and treat $-\mathrm{s} / \mathrm{z} /$ as the marker of plurality. On the other hand the syllable structure of non-locutors (3 SG/PL) - VC - is in opposition to locutors (1-2 SG/PL) - CV.

\section{Bantu pronominal systems in the context of morphemic/submorphemic neutralizations}

Bantu pronominal systems have not yet been analyzed within this theoretical framework (except Swahili in [7]. This presentation deals with comparative analysis of the distribution of morphemic and submorphemic neutralizations in pronominal paradigms of the Bantu languages from different zones and Proto-Bantu reconstruction. In the tables the morphemic neutralizations are marked with dark grey, the intermediate cases when the morphemes are segmentally equal but different in tone - with grey, submorphemic netralizations - with light grey. $1 / 2$ person neutralization is marked by red, $2 / 3$ person neutralization - by rose, sg/pl neutralization - by blue, cascade $1 / 2 / 3$ neutralization by green. The data are from Nurse \& Philippson [9], Segerer [10]. For the further analysis the languages under consideration are distributed into 3 areal groups: North-West (Cross River, zones A, C, D), East (zones G, J, P), South and South-West (zones K, R, S).

Analysis of Table 1.

Here the languages of the North-West areal of the Bantu languages are reperesented. Still in Proto-Bantu the pronominal paradigm is "glued" together in all aspects ( $1 / 2$ persons, $2 / 3$ persons, $\mathrm{Sg} / \mathrm{Pl}$ ). We can see the $2 / 3$ person neutralization in $\mathrm{Sg}$ (morphemic with tone difference in Subject and Tonique ${ }^{1}$ paradigms, submorphemic - in Object paradigm), while in $\mathrm{Pl}$ we have the context of opposition - no neutralizations at all. In an opposite way the distinction between 1 and 2 persons is realized in Sg, while in $\mathrm{Pl}$ we have a context of submorphemic neutralization in all 3 paradigms. The Sg/Plopposition is submorphemically neutralized for 3 person Subject and 2 person Object, being distinct in the other contexts. The reflexes of the proto-system in modern languages are formally rather different from language to language, but the idea of obligatory neutralizations of all oppositions relevant to pronominal paradigm is kept in all the four languages the locus and type of neutralizations being different: for instance, in Ibibio (Cross-River) $1 / 2$ person opposition is morphemically neutralized in Subject and Object $\mathrm{Pl}$, and submorphemically - in

1 Tonique (or Emphatic) series of pronouns occur in emphatic contexts, in nominal predication and, sometimes, for indirect objects, while subject and object series are used in regular verbal predication for two main arguments. 
Table 1. Morphemic and submorphemic neutralizations in Proto-Bantu, Cross River and zones A, C, D (North-West)

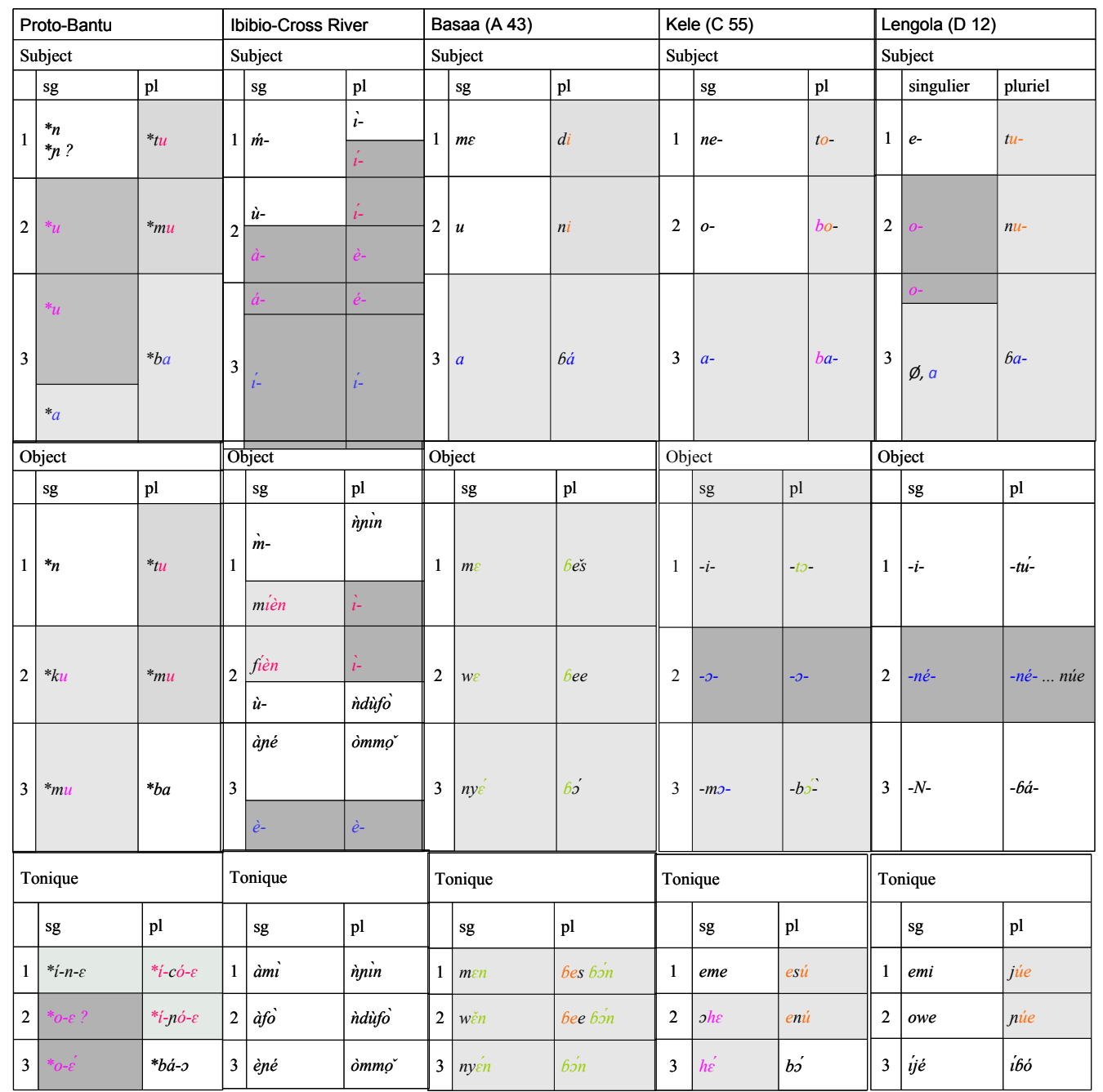

Object Sg, 2/3 person opposition is morphemically neutralized in Sg and Pl Subject allomorphs. $\mathrm{Sg} / \mathrm{Pl}$ opposition demonstrates the morphemic neutralization in 3 person Subject and Object. This analysis supports the idea of the complementary distribution of both distinction and neutralization contexts and morphemic and submorphemic neutralizations: a lot of morphemic neutralizations (dark grey) in Ibibio correspond to quite few submorphemic ones (light grey); a lot of neutralizations in Subject and Object paradigms leads to an absolute absence of neutralizations in Tonique paradigm. Basaa is different to Ibibio in a sense that it prefers only submorpemic netralizations, while Kele ( 1 morhemic neutralization) and Lengola ( 2 morhemic neutralizations) seems to be somewhere in between in this sense. In Basaa we can also see an example of the so-called "cascade" neutralizations ${ }^{2}$ in Tonique paradigm: 1/2/3 persons are submorphemically

\footnotetext{
${ }^{2}$ I borrowed this term from Guillaume Segerer [11].
} 
neutralized for both Sg and Pl. However, as it is evident from the table, all the languages still keep all the relevant neutralizations $(1 / 2,2 / 3, \mathrm{Sg} / \mathrm{Pl})$.

Table 2. Morphemic and submorphemic neutralizations in Proto-Bantu and zones G, J, P (East)

\begin{tabular}{|c|c|c|c|c|c|c|c|c|}
\hline & \multicolumn{2}{|c|}{ Proto-Bantu } & \multicolumn{2}{|c|}{ Swahili (G 42) } & \multicolumn{2}{|c|}{ Kinyarwanda (J 61) } & \multicolumn{2}{|c|}{ Makonde (P 23) } \\
\hline & $\mathrm{Sg}$ & $\mathrm{Pl}$ & $\mathrm{Sg}$ & P1 & $\mathrm{Sg}$ & Pl & $\mathrm{Sg}$ & Pl \\
\hline & \multicolumn{8}{|c|}{ Subject } \\
\hline \multirow[t]{2}{*}{1} & $*_{n, n} n$ ? & $* t u$ & $n i$ & $t u$ & $n$ & $t u$ & $n i$ & $t u$ \\
\hline & & & & & & & $n g u$ & \\
\hline 2 & $* u$ & $*_{m u}$ & $u$ & $m(u)$ & $u$ & $m u$ & u & $m u$ \\
\hline \multirow[t]{3}{*}{3} & $* u$ & $* b a$ & $y u$ & $w a$ & $a$ & $b a$ & $a$ & $v a$ \\
\hline & $*_{\mathrm{a}}$ & & $\mathrm{a}$ & & & & & \\
\hline & \multicolumn{8}{|c|}{ Object } \\
\hline 1 & $*_{n}$ & $* t u$ & $n i$ & $t u$ & $n$ & $t u$ & $n g u$ & $t u$ \\
\hline 2 & $* k u$ & $*_{m u}$ & $k u$ & $w a$ & $k u$ & $b a$ & $k u$ & $m u$ \\
\hline 3 & $*_{m u}$ & $* b a$ & $m$ & $w a$ & $m u$ & $b a$ & $m u$ & $w a$ \\
\hline
\end{tabular}

Analysis of table 2 .

The languages of the eastern areal have much more unified pronominal systems comparing to the north-western areal, and it corresponds quite well to the historicalcomparative data concerning the spread of the Bantu languages. Nevertheless, the systems are still different, but demonstrate all of the afore-mentioned oppositions $(1 / 2$, $2 / 3, \mathrm{Sg} / \mathrm{Pl}$ ) evidently preferring submorphemic ones. Swahili and Kinyarwanda have only one morphemic neutralization for $2 / 3 \mathrm{Pl}$ Object (cf. with Proto-Bantu, where the only morphemic neutralization is of 2/3 Sg Subject), while Makonde realizes all the oppositions in submorphemic way. There is also a correlation between the preference of submorphemic neutralizations and the presence of cascade (1/2/3 persons) neutralization for Sg Object paradigm in Makonde (cf. with Basaa from table 1). Sg/Pl neutralization can be observed only in 3 person Subject paradigm.

In the Southern areal we can see again that all the neutralizations $(1 / 2,2 / 3, \mathrm{SG} / \mathrm{Pl})$ take place in all the languages under concideration. In Umbundu we can see $2 \mathrm{SG} / 2 \mathrm{Pl}$ morphemic neutralization which we observed in Kele and Lengola, but did not see in the Eastern areal. The only cascade ( $1 / 2 / 3$ persons) neutralization in this group occurs in Luvale, while it could rather be expected in Mbukushu where there is no morphemic neutralizations, but in Luvale Object paradigm where this neutralization appears there are no morphemic neutralizations either, so the rule "cascade oppositions appear in case there are no full morphemic oppositions in the paradighm" still works. In Luvale we can see another interesting phenomenon: if some "stable" neutralization (eg. 2 SG/Pl Object neutralization which is present in all the languages of $\mathrm{K}, \mathrm{R}, \mathrm{S}$ zones except Luvale) is lost via innovation (2 Pl Object $m i$ in Luvale instead of common $m u$ ) another neutralization appears to keep the important formal link between sg and pl. (1 SG/Pl $n g \boldsymbol{u} / t \boldsymbol{u}$ ). Innovative $1 \mathrm{Sg}$ Object $n g u$ instead of $n i$ appears and keeps it actual. In Mbukushu we can see innovative forms for 2 and $3 \mathrm{Sg}$ Subject ( $g h u$ and gha) which are not attested in all the languages under consideration, but despite there innovative character comparing to Proto-Bantu they still keep the same very stable for many languages 2/3 SG Subject pronouns neutralization. However the analogy (submorphemic tuning) is provided by evidently innovative consonant ([gh]), but not by vowels as in Proto-Bantu and many 
Table 3. Morphemic and submorphemic neutralizations in Proto-Bantu and zones K, R, S (South, South-West)

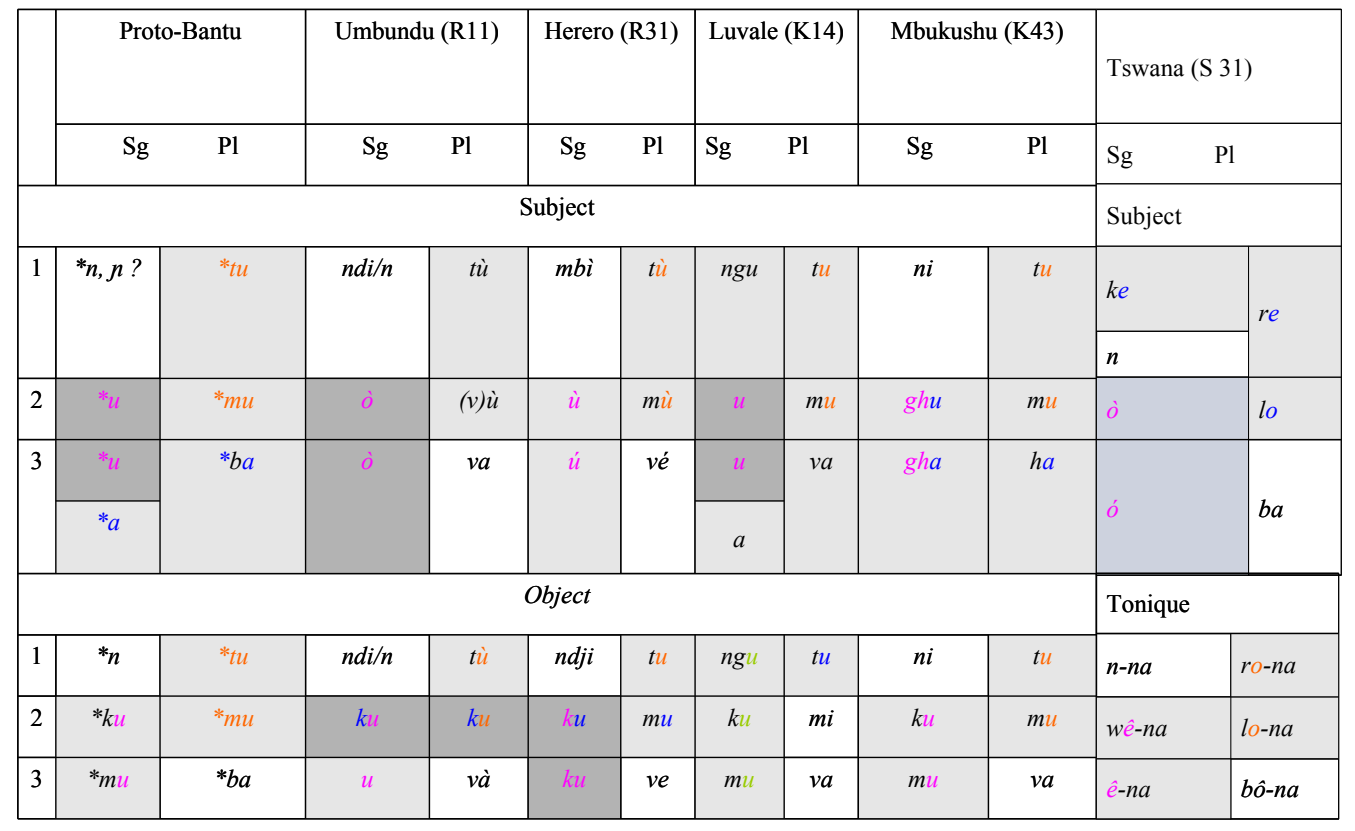

other languages. In Subject Tswana paradigm we can see a very rare Sg/Pl submorpemic neuitralization for the 1-st person, which was met only in Makonde Object paradigm. Its appearance can be explained as the compensation of the loss of the same SG/PL neutralization in the 3 SG which occurs in Proto-Bantu and is very "popular" among other languages.

\section{Conclusions}

1) Morphemic and submorphemic neutralizations are often in complementary distribution, the more morphemic neutralizations in the paradigm, the less submorphemic ones.

2) The neutralizations are not "occasional", but rather systematic.

3) It often happens to be important for paradigms to keep the structure of oppositions and neutralizations rather than forms.

4) All the neutralizations $(1 / 2,2 / 3, \mathrm{SG} / \mathrm{PL})$ take place in all the languages despite the difference in forms. Sometimes $1 / 2$ and $2 / 3$ neutralizations are realized in cascade form (Basaa). It shows that all these neutralizations are crucially important to "glue" pronominal paradigms.

5) 1 SG tends to be in opposition to other pronouns and very seldom participates in neutralizations.

6) 3 person is "responsible" for SG/PL neutralization, plural - for $1 / 2$ neutralization, $2 / 3$ is distributed in both SG and PL. $1 / 2$ neutralization tends to be submorphemic, while other types of neutralizations can be both morphemic and submorphemic. 


\section{Литература}

1. Cysouw Michael. The Paradigmatic Structure of Person Marking. (Oxford Studies in Typology and Linguistic Theory). Oxford: Oxford University Press, 2003.

2. Pozdniakov Konstantin. The Complementary Distribution of Sub-Morphemic and Morphemic Neutralizations as a Tendency in the Languages with Noun Classes // St.-Petersburg Journal of African Studies. St. Petersburg, 1993. N 1. P. 16-40.

3. Pozdniakov Konstantin. Micromorphologie ou morphologie de paradigme? // Bulletin de la Société de linguistique de Paris. 2003. T.XCVIII, fasc. 1. P.3-52.

4. Поздняков К. И. О природе и функциях внеморфемных знаков // Вопросы языкознания. 2009. № 6. С. 35-64.

5. Якобсон Р.О. Морфологические наблюдения над славянским склонением // Роман Якобсон. Избранные работы. М., 1985. С. 176-197.

6. Zheltov Alexander. Le système des marqueurs de personne en gban: Le pronom: Un morphème syncrétique ou un syncrétisme des morphèmes? // Mandenkan. Paris, 2005. N 41. P. 23-28.

7. Желтов А.Ю. Языки нигер-конго: структурно-динамическая типология. СПб.: Изд-во С.-Петерб. ун-та, 2008.

8. Pozdniakov Konstantin. Analogical changes in Niger-Congo pronominal systems // Personal pronouns in Niger-Congo Languages. International workshop. St. Petersburg, 2010. September 13-15. Abstracts and papers. P. 121-131.

9. The Bantu Languages / eds. D. Nurse, G. Philippson. London; New-York: Routledge, 2003.

10. Segerer Guillaume. Le marque personnelles dans les langues africaines [base de donnees en ligne] (2002-2010). URL: http://sumale.vjf.cnrs.fr/pronoms (дата обращения: 15.06.2016).

11. Segerer Guillaume. Qui se ressemble sassemble. Analyse quantitative de l'unification par analogie au sein des systèmes de marques personnelles // Personal pronouns in Niger-Congo Languages. International workshop. St. Petersburg, September 13-15, 2010. Abstracts and papers. P. 144-151.

Для цитирования: Желтов А. Ю. Сравнительный анализ морфемных и субморфных нейтрализаций в парадигмах личных местоимений языков банту // Вестник Санкт-Петербургского университета. Серия 13. Востоковедение. Африканистика. 2016. Вып. 4. С. 13-21. DOI: 10.21638/11701/spbu13.2016.402.

\section{References}

1. Cysouw Michael. The Paradigmatic Structure of Person Marking. (Oxford Studies in Typology and Linguistic Theory). Oxford, Oxford University Press. 2003.

2. Pozdniakov Konstantin. The Complementary Distribution of Sub-Morphemic and Morphemic Neutralizations as a Tendency in the Languages with Noun Classes. St. Petersburg Journal of African Studies, 1993, no. 1, pp. 16-40.

3. Pozdniakov Konstantin. Micromorphologie ou morphologie de paradigme? Bulletin de la Société de linguistique de Paris, 2003, vol.XCVIII, fasc. 1, pp. 3-52.

4. Pozdniakov K.I. O prirode i funktsiiakh vnemorfemnykh znakov [About the nature and functions of submorphemic sighns]. Voprosy iazykoznaniia [Matters of Language studies], 2009, no. 6, pp.35-64. (In Russian)

5. Jakobson R. [O Morphological observations at Slavic declension]. Roman Iakobson. Izbrannye raboty [Roman Jakobson. Selected works]. Moscow, 1985, pp. 176-197. (In Russian)

6. Zheltov Alexander. Le système des marqueurs de personne en gban: Le pronom: Un morphème syncrétique ou un syncrétisme des morphèmes? Mandenkan. Paris, 2005, no. 41, pp. 23-28.

7. Zheltov A. Yu. Iazyki niger-kongo: strukturno-dinamicheskaia tipologiia [The Niger-Congo lan-
[The guages: structural-dynamic typology]. St. Petersburg, St. Petersburg University Press, 2008. (In Russian)

8. Pozdniakov Konstantin. Analogical changes in Niger-Congo pronominal systems. Personal pronouns in Niger-Congo Languages. International workshop. St. Petersburg, September 13-15, 2010, Abstracts and papers, pp. $121-131$

9. The Bantu Languages. Eds. D. Nurse, G. Philippson. London, New-York, Routledge, 2003.

10. Segerer Guillaume. Le marque personnelles dans les langues africaines [base de donnees en ligne] (2002-2010). Available at: http://sumale.vjf.cnrs.fr/pronoms (accessed: 15.06.2016).

11. Segerer Guillaume. Qui se ressemble s'assemble. Analyse quantitative de l'unification par analogie au sein des systèmes de marques personnelles. Personal pronouns in Niger-Congo Languages. International workshop. St. Petersburg, September 13-15, 2010, Abstracts and papers, pp. 144-151. 
For citation: Zheltov A. Yu. Comparative analysis of morphemic and submorhemic neutralizations in Bantu pronominal paradigms (what they are for, and what they say about the language change). Vestnik of Saint Petersburg University. Series 13. Asian Studies. African Studies, 2016, issue 4, pp. 13-21. DOI: 10.21638/11701/ spbu13.2016.402.

Received: July 7, 2016 Accepted: September 8, 2016

\section{Контактная информация}

Желтов Александр Юрьевич — доктор филологических наук, доцент; ajujeltov@mail.ru Zheltov A. Yu. — PhD; ajujeltov@mail.ru 